\title{
SOWING DEPTHS OF BRACHIARIA IN INTERCROPPING WITH CORN IN NO TILLAGE PLANTING
}

\author{
RODOLFO DE N. GAZOLA ${ }^{1}$, LUIZ M. M. DE MELO ${ }^{2}$, RAÍSSA P. DINALLI ${ }^{3}$, \\ MARCELO C. M. TEIXEIRA FILHO ${ }^{4}$, CÁSSIA M. DE P. GARCIA ${ }^{5}$
}

\begin{abstract}
The forage production in crop-livestock integration is critical both for formation of straw for no tillage planting and food for livestock farm. The experiment was conducted in the autumn/winter of 2009 and 2010, in the city of Selvíria - state of Mato Grosso do Sul - MS, Brazil, at Experimental Station of FEIS/UNESP. The objective was to evaluate the optimal depth for deposition of seeds of two Brachiaria species intercropped with corn with emphasis on grain yield and straw. The experimental design was a randomized block design in a factorial scheme $3 \times 3$, with four replications. The main treatments were two species of Brachiaria (Urochloa brizantha "Marandú" and Urochloa ruziziensis), which seeds were mixed with corn fertilizer and a control treatment (without intercropping). Secondary treatments consisted of three depths $(8 ; 10$ and $16 \mathrm{~cm})$ in the deposition of fertilizer (in the consortium and the control treatments). The intercropping corn with Brachiaria produced similar amounts of straw. The straw total production was higher when intercropped and decreased with depth. The consortium with $U$. ruziziensis provided higher grain yield of corn in relation to $U$. brizantha, in 2010. The sowing depth of forages did not affect corn yield.
\end{abstract}

KEYWORDS: crop-livestock integration, mechanization, grain yield, Urochloa brizantha, Urochloa ruziziensis.

\section{PROFUNDIDADE DE SEMEADURA DE BRAQUIÁRIAS EM CONSORCIAÇÃO COM MILHO EM PLANTIO DIRETO}

RESUMO: A produção de forragem na integração lavoura-pecuária é de suma importância, tanto para alimentação animal como para formação de palhada para plantio direto. O experimento foi conduzido no outono/inverno de 2009 e 2010, em Selvíria - MS, na Fazenda de Ensino, Pesquisa e Extensão da FEIS/UNESP. O objetivo foi avaliar a profundidade mais adequada para deposição das sementes de duas espécies de braquiárias em consórcio com milho, com ênfase para a produtividade do milho e formação de palha. O delineamento experimental foi em blocos ao acaso, em esquema fatorial 3 x 3, com quatro repetições. Os tratamentos principais foram duas espécies de braquiárias (Urochloa brizantha cv. Marandú e Urochloa ruziziensis), cujas sementes foram misturadas ao fertilizante do milho, e um tratamento-testemunha (sem consórcio). Os tratamentos secundários constituíram-se em três profundidades $(8 ; 10$ e $16 \mathrm{~cm}$ ) de deposição do fertilizante (em consórcio e na testemunha). Os consórcios de milho com braquiária produziram quantidades de palha semelhantes. A produção total de palha foi maior nos consórcios e nas menores profundidades. $\mathrm{O}$ consórcio com $U$. ruziziensis propiciou maior produtividade de grãos de milho em relação ao com $U$. brizantha, em 2010. As profundidades de semeadura das forrageiras não afetaram a produtividade de milho.

PALAVRAS-CHAVE: integração lavoura-pecuária, mecanização, produtividade de grãos, Urochloa brizantha, Urochloa ruziziensis.

\footnotetext{
${ }^{1}$ Eng ${ }^{\mathrm{o}}$ Agrônomo, Mestrando do Programa de Pós-Graduação em Agronomia, Faculdade de Engenharia (FE/Unesp), Departamento de Fitossanidade, Engenharia Rural e Solos, Ilha Solteira - SP, rodolfodng@ @otmail.com.

${ }^{2}$ Eng $^{\mathrm{o}}$ Agrônomo, Professor Titular, Departamento de Fitossanidade, Engenharia Rural e Solos, UNESP, Ilha Solteira - SP.

${ }^{3}$ Eng ${ }^{\mathbf{a}}$ Agrônoma, Mestranda do Programa de Pós-Graduação em Agronomia, Departamento de Fitossanidade, Engenharia Rural e Solos, UNESP, Ilha Solteira - SP.

${ }^{4}$ Eng ${ }^{0}$ Agrônomo, Professor Dr. Substituto, Departamento de Fitossanidade, Engenharia Rural e Solos, UNESP, Ilha Solteira - SP.

${ }^{5}$ Zootecnista, Mestranda, Departamento de Fitossanidade, Engenharia Rural e Solos, UNESP, Ilha Solteira - SP.

Recebido pelo Conselho Editorial em: 16-12-2011
}

Aprovado pelo Conselho Editorial em: 6-8-2012 


\section{INTRODUCTION}

Forage production in crop-livestock integration is critical for formation of straw, providing ground cover and food for livestock. According to MELLO et al. (2004), this system integrates the two activities with the goals of maximizing rational land use, verticalize and diversify production, minimize costs and add value to products by taking advantage of the features and benefits that provide an activity to another. However, because it is a new system, there are questions regarding to soil compaction effects on later crops and on the amount of waste straw for ground cover.

The consortium of off-season corn with other species is an important alternative for the production of grain and straw. It can enable no tillage planting in the Midwest Region of Brazil (CECCON, 2007). Within this scenario, the establishment of the crop-livestock system using cover crops intercropped with corn is an exploration option, maximizing the productive use of the soil, adding value for grain production and forage for livestock (SILVA et al., 2008).

The Urochloa ruziziensis has been recommended for integrated crop livestock mainly by providing rapid ground cover, have high quality composition, excellent nutrient recycling, facilities in its desiccation and uniform seed production (TRECENTI, 2005). Among the different methods tested in cultivation of off-season corn crop integrated with Urochloa ruziziensis held by BRAMBILLA et al. (2009), the consortium corn plus brachiaria in rows and inter rows yielded the highest productivity of dry straw, favoring ground cover. For BARDUCCI et al. (2009), the best consortium to be used is corn with Urochloa brizantha "Marandú".

Several authors found viability of maize intercropped with Brachiaria forage (currently named Urochloa), indicating that the production of forage dry matter does not interfere in corn yield in crop-livestock integration (PEQUENO et al., 2006; PEREIRA et al., 2009; GARCIA et al., 2010; RICHART et al., 2010). However, other authors found that cultivation of corn intercropped with Urochloa brizantha (BORGHI et al., 2006; BORGHI \& CRUSCIOL, 2007; CHIODEROLI, 2010) and Urochloa ruziziensis (PARIZ et al., 2011) promoted lower yields of corn grains.

Deposition of the sowing fertilizer mixed with the seeds of forage species at depths below $5 \mathrm{~cm}$ allows the delayed germination and emergence, in order to decrease competition with the grain producer crop (KLUTHCOUSKI et al. 2000; FOLONI et al., 2009).

Regarding the depth of seeding of forage plants, the best emergencies of $U$. brizantha, $U$. decumbens and Panicum maximum "Tanzânia" were found in the sowing depth of $5 \mathrm{~cm}$ (REZENDE et al., 2007). According to CECCON et al. (2008), the best germination of $U$. ruziziensis were observed in sowings performed between 4 and $6 \mathrm{~cm}$ deep, with better performance observed in nucleated and coated seeds. However, in order to have greater potential emergence of $U$. brizantha it is necessary to sow it $2.5 \mathrm{~cm}$ deep in the soil; however, if the seeds are deposited at depths below $5 \mathrm{~cm}$, can occur serious stand problems (FOLONI et al., 2009). However, PACHECO et al. (2010) found that there was delay in seedling emergence from $10 \mathrm{~cm}$ sowing of the $U$. brizantha and $8 \mathrm{~cm}$ deep for the $U$. decumbens, U. ruziziensis and species, and that $U$. brizantha, $U$. decumbens and $U$. ruziziensis forage species showed greater capacity of dry matter production $\left(\mathrm{g}\right.$ plant $\left.{ }^{-1}\right)$ up to $8 \mathrm{~cm}$ deep.

Given the above, the objective of this study was to evaluate the optimal depth for deposition of seeds of two species of Brachiaria (Urochloa brizantha "Marandú" and Urochloa ruziziensis) intercropped with corn, with emphasis on corn grain yield and straw production.

\section{MATERIAL AND METHODS}

The experiment was conducted in 2009 and 2010, at the Experimental Station (FEPE) in Selvíria - MS, of the Engineering College of Ilha Solteira (FEIS/UNESP), located approximately in the geographic coordinates $51^{\circ} 24^{\prime} \mathrm{W}$ and $20^{\circ} 20^{\prime} \mathrm{S}$, with local altitude of 350 meters with $4 \%$ slope. The experimental area was classified as DISTROFERRIC RED LATOSOL, with clayey texture (EMBRAPA, 2006). The average annual rainfall is $1,370 \mathrm{~mm}$, the average annual temperature is 
$23.5^{\circ} \mathrm{C}$ and relative humidity is between 70 and $80 \%$ (annual average). The values of these averages, recorded during the experiments, are given in Figure 1.

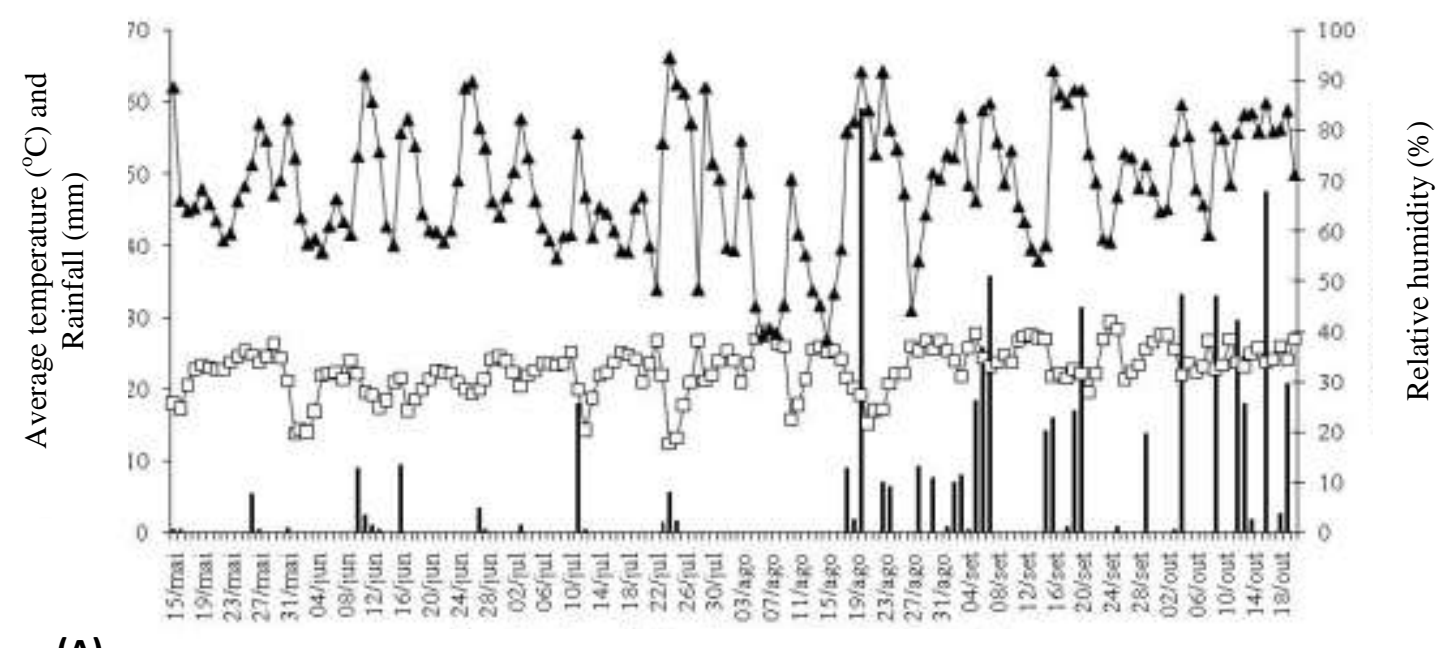

(A)

Period of the experiment (day/month

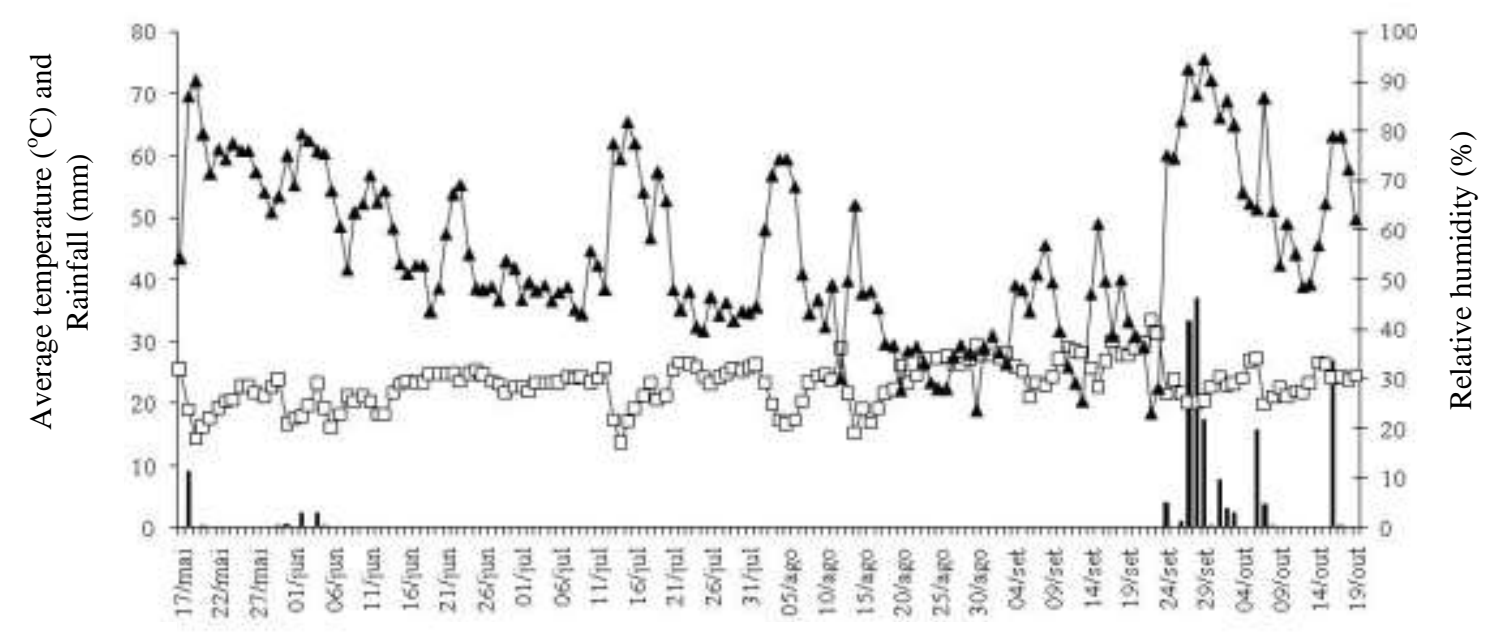

(B)

Period of the experiment (day/month

Rainfall

$\rightarrow \square-$ Average Temp.

$\rightarrow$ RH

FIGURE 1. Rainfall (mm), average temperature $\left({ }^{\circ} \mathrm{C}\right)$ and relative humidity $(\%)$ during the experiments with corn intercropped with brachiaria. Selvíria - MS, 2009 (A) and 2010 (B).

The experimental design used was a randomized block design with nine treatments in $3 \times 3$ factorial design with four replications. The main treatments were of two species of Brachiaria (Urochloa brizantha "Marandú" and Urochloa ruziziensis), whose seeds were mixed with corn fertilizer in a treatment control (single corn). Secondary treatments were constituted at deposition of fertilizer in three depths $(8 ; 10$ and $16 \mathrm{~cm})+$ seeds of forage (in consortium and control treatment). As reported by KLUTHCOUSKI et al. (2000) and FOLONI et al. (2009), the deposition of seeds of forage species at depths below $5 \mathrm{~cm}$ allows the delayed germination and emergence, in order to decrease competition with the grain producer crop.

The plots consisted of seven rows of corn, spaced apart by $0.45 \mathrm{~m}$; they were $20 \mathrm{~m}$ long and useful area corresponding to three centerlines of $5 \mathrm{~m}$ each. 
The corn sowing intercropped with Brachiaria was held on 05/15/2009 and 05/17/2010 (first and second season, respectively) in no-tillage system (NTS), in an area previously desiccated with glyphosate herbicide $\left(2,160 \mathrm{~kg}\right.$ i.a. $\left.\mathrm{ha}^{-1}\right)$ in total area. The simple hybrid used was the DKB $390 \mathrm{Y}$ trademark, of early cycle targeting at a population of 60.000 plants $\mathrm{ha}^{-1}$, with spacing of $0.45 \mathrm{~m}$, sowing rate of 2.7 seeds per meter $(5 \mathrm{~cm}$ depth for corn sowing). Corn seeds were treated with Tiodicarbe at a dosage of $600 \mathrm{~g}$ i.a. per $100 \mathrm{~kg}$ of seed.

The sowing rate of brachiarias was $8 \mathrm{~kg} \mathrm{ha}^{-1}$ of certified seeds of "Marandú" and Urochloa ruzizienses with cultural value of $76 \%$, regardless of the form of intercropping. Brachiaria seeds were mixed with fertilizer and packed in the fertilizer compartment of the seeder, minutes before sowing. The sowing depth constituted treatments; these forage seeds were distributed and located below the corn seed. The depths adjustments were made by the pressure of the concentric spring assembly responsible for the depth of fertilizer deposition. Two days after the sowing was performed one application of the herbicide desiccant of contact paraquat $\left(240 \mathrm{~g} \mathrm{i}^{\mathrm{a} . \mathrm{ha}^{-1}}\right)$; its application volume was $200 \mathrm{~L} \mathrm{~h}^{-1}$, in order to eliminate the seedlings that emerged after the first drying. The seeder used was Marchesan, Supreme model with pneumatic distribution of seeds, configured with furrower of rod type mechanism for disposal of the fertilizer, furrower of double disc for seed deposition and concave compaction wheel, pulled by a tractor of $77.23 \mathrm{~kW}$ rated power.

The soil chemical characteristics determined prior to the experiment (2009), according to the methodology proposed by RAIJ (1991), showed the following results: $15 \mathrm{mg} \mathrm{dm}^{-3}$ of P (resin); $20 \mathrm{~g} \mathrm{dm}^{-3}$ O.M.; $4.8 \mathrm{pH}\left(\mathrm{CaCl}^{2}\right) ; \mathrm{K}, \mathrm{Ca}, \mathrm{Mg}, \mathrm{Al}+\mathrm{H}=2.2 ; 12.0 ; 7.0$ and $16.0 \mathrm{mmol} \mathrm{dm}^{-3}$, respectively; and $57 \%$ of base saturation. The sowing mineral fertilization was based on the chemical characteristics of the soil, and it was applied $24 \mathrm{~kg} \mathrm{ha}^{-1}$ of $\mathrm{N}, 84 \mathrm{~kg} \mathrm{ha}^{-1}$ of $\mathrm{P}_{2} \mathrm{O}_{5}$ and $48 \mathrm{~kg} \mathrm{ha}^{-1}$ of $\mathrm{K}_{2} \mathrm{O}$, corresponding to $300 \mathrm{~kg} \mathrm{ha}^{-1}$ of the commercial formula 08-28-16. Fertilization was performed when corn plants were at the V4 stage, using $72 \mathrm{~kg} \mathrm{ha}^{-1}$ of $\mathrm{K}_{2} \mathrm{O}$ (potassium chloride) and $135 \mathrm{~kg} \mathrm{ha}^{-1}$ of $\mathrm{N}$ (urea). Before the covering fertilization, the atrazine herbicide was applied $\left(1.0 \mathrm{~kg}\right.$ i.a. ha $\left.{ }^{-1}\right)$. To control the larvae (Spodoptera frugiperda) it was performed an application of lufenuron (rate of $15 \mathrm{~g}$ i.a. ha ${ }^{-1}$ ). The water supply was made by the Center Pivot Irrigation System, with a water depth of approximately $14 \mathrm{~mm}$ and irrigation interval of 3 days, following the farm management routine.

In the two years of cultivation, the experimental area had soybeans as preceding crop. After the first corn crop intercropped with brachiarias (2009), the area was dried out for soybean sowing. After the harvest of this crop, it was proceeded with the desiccation in total area and then the corn sowing intercropped with brachiarias again (2010).

The corn crops and the brachiarias dry matter were held on 10/20/2009 and 10/19/2010 (first and second season, respectively). The brachiaria dry matter was assessed in the row, collecting only the Brachiaria straw in $2 \mathrm{~m}$ of three planting rows of each parcel. To evaluate production of grain and dry straw of the corn, it was weighed all plants collected in three rows of $5 \mathrm{~m}$ of each parcel subjected to mechanical trail. After the trail, the grains were separated, weighed and the values was corrected for the $13 \%$ of wet basis. It was deducted the weight of the grains thereby obtaining the weight of the fresh straw. The samples were dried in an oven with forced air circulation for 72 hours at $65{ }^{\circ} \mathrm{C}$ to determine the $\%$ of moisture and subsequent calculation of dry matter production per hectare of straw.

Data were subjected to analysis of variance and treatment averages were compared using the Tukey's test at 5\% probability. Statistical analysis was performed using the SISVAR program (FERREIRA, 2008).

\section{RESULTS AND DISCUSSION}

Analyzing the results of the Brachiaria and corn dry matter and total straw (Table 1), it is found significant effects in both years for Brachiaria dry matter in different depths and for total 
straw dry matter in different cultivation systems and deposition depths of corn seed mixed with the fertilizer.

Table 1 shows that the dry matter production of Brachiaria was higher in shallow seeding, and this difference was more significant for $U$. brizantha in both years. These results are due to shadowing provided by corn plants on this forage as a function of the delay in the emergence of the plants due to greater seeding depth $(16 \mathrm{~cm})$. Regarding the low dry matter production of $U$. brizantha when sowing it deeper, this is probably due to lower seed germination and seedling emergence. According to PACHECO et al. (2010), deeper sowings of $U$. brizantha and $U$. decumbens result in lower density and stand of plants, requiring thus increasing the density of seeds to achieve the ideal stand of the plant cover. However, this measure implies an increase in the cost of production, what may prevent the use of deeper sowing to delay the emergence of coverage plants in ILP.

TABLE 1. Average values of brachiaria dry matter (BDM), corn dry matter (CDM) and total straw dry matter (TDM) in intercropping system of brachiaria with corn, submitted to three depths of seed deposition mixed with fertilizer in no tillage corn. (Selvíria - MS, 2009 and 2010).

\begin{tabular}{|c|c|c|c|c|c|c|c|}
\hline & \multicolumn{3}{|c|}{2009} & \multicolumn{3}{|c|}{2010} \\
\hline & & $\mathrm{BDM}$ & CDM & TDM & $\mathrm{BDM}$ & CDM & TDM \\
\hline & & $\left(\mathrm{kg} \mathrm{ha}^{-1}\right)$ & $\left(\mathrm{kg} \mathrm{ha}^{-1}\right)$ & $\left(\mathrm{kg} \mathrm{ha}^{-1}\right)$ & $\left(\mathrm{kg} \mathrm{ha}^{-1}\right)$ & $\left(\mathrm{kg} \mathrm{ha}^{-1}\right)$ & $\left(\mathrm{kg} \mathrm{ha}^{-1}\right)$ \\
\hline \multirow{3}{*}{$\begin{array}{l}\text { Types of crops } \\
\text { (T) }\end{array}$} & $\mathrm{SC}$ & 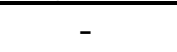 & $9,177 \mathrm{a}$ & $9,177 \mathrm{~b}$ & 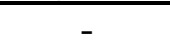 & $9,367 \mathrm{a}$ & $9,367 \mathrm{~b}$ \\
\hline & $\mathrm{CBb}$ & $2,461 \mathrm{a}$ & $8,763 \mathrm{a}$ & $11,224 \mathrm{a}$ & $2,628 \mathrm{a}$ & $8,850 \mathrm{a}$ & $11,477 \mathrm{a}$ \\
\hline & $\mathrm{CBr}$ & $2,082 \mathrm{a}$ & $8,900 \mathrm{a}$ & $10,982 \mathrm{ab}$ & $2,248 \mathrm{a}$ & $9,242 \mathrm{a}$ & $11,490 \mathrm{a}$ \\
\hline D.M.S. $(5 \%)$ & & 826 & 1,629 & 2,022 & 786 & 1,467 & 1,777 \\
\hline \multirow{3}{*}{$\begin{array}{l}\text { Sowing depths } \\
\text { (D) }\end{array}$} & $8 \mathrm{~cm}$ & $3,326 \mathrm{a}$ & $8,560 \mathrm{a}$ & $10,778 \mathrm{ab}$ & $3,576 \mathrm{a}$ & $8,958 \mathrm{a}$ & $11,342 \mathrm{a}$ \\
\hline & $10 \mathrm{~cm}$ & $2,813 \mathrm{a}$ & $9,569 \mathrm{a}$ & $11,444 \mathrm{a}$ & $2,963 \mathrm{a}$ & $9,675 \mathrm{a}$ & $11,650 \mathrm{a}$ \\
\hline & $16 \mathrm{~cm}$ & $676 \mathrm{~b}$ & $8,711 \mathrm{a}$ & $9,162 \mathrm{~b}$ & $776 \mathrm{~b}$ & $8,825 \mathrm{a}$ & $9,342 \mathrm{~b}$ \\
\hline D.M.S. (5\%) & & 1,238 & 1,629 & 2,022 & 1,173 & 1,467 & 1,777 \\
\hline \multirow{3}{*}{ F Value } & $\mathrm{T}$ & $1.059^{\mathrm{ns}}$ & $0.209^{\mathrm{ns}}$ & $3.822 *$ & $1.059^{\mathrm{ns}}$ & $0.422^{\mathrm{ns}}$ & $5.906^{* *}$ \\
\hline & D & $19.383 * *$ & $1.392^{\mathrm{ns}}$ & $4.204 *$ & $21.257 * *$ & $1.213^{\mathrm{ns}}$ & $6.206 * *$ \\
\hline & $\mathrm{T} \times \mathrm{D}$ & $0.503^{\mathrm{ns}}$ & $0.668^{\text {ns }}$ & $1.864^{\mathrm{ns}}$ & $0.503^{\mathrm{ns}}$ & $0.603^{\mathrm{ns}}$ & $2.536^{\mathrm{ns}}$ \\
\hline C.V. (\%) & & 39.75 & 17.85 & 18.95 & 37.04 & 15.71 & 16.17 \\
\hline General Average & & 2272 & 8947 & 10461 & 2438 & 9153 & 10778 \\
\hline
\end{tabular}

Averages followed by the same letter in the column do not differ by the Tukey's test, at a 5\% probability. Note: SC (single corn), $\mathrm{CBb}(\mathrm{Corn}+U$. brizantha $)$ and $\mathrm{CBr}(\mathrm{Corn}+U$. ruziziensis $)$.

PACHECO et al. (2010) found that there was delay in seedling emergence from sowing of $10 \mathrm{~cm}$ for the $U$. brizantha and $8 \mathrm{~cm}$ deep for the species $U$. decumbens, $U$. ruziziensis and $P$. maximum, and that forage species $U$. brizantha, $U$. decumbens and $U$. ruziziensis showed greater capacity for dry matter production $\left(\mathrm{g}_{\text {plant }}{ }^{-1}\right.$ ) of up to $8 \mathrm{~cm}$ deep. In a similar study conducted by REZENDE et al. (2007), the highest germination occurred with the seeds of $U$. decumbens and $U$. brizantha, being the highest germination observed at depths of 2.5 and $5.0 \mathrm{~cm}$. For seeds of $U$. decumbens, the lowest percentage of germination was observed at a depth of $15.0 \mathrm{~cm}$.

OLIVEIRA et al. (1996), working with Brachiaria, also observed delay in the emergence of plants as a function of sowing depth, and the distribution of seeds to $10 \mathrm{~cm}$ provided a delay of around five days in seedling emergence, enough to lag it in relation to annual intercropped crops. FOLONI et al. (2009), working with different depths of forage sowing, concluded that the best sowing depth in terms of speed of seedling emergence for Brachiaria was $2.5 \mathrm{~cm}$ in the soil and that the sowing of $10 \mathrm{~cm}$ deep almost prevented the emergence of $U$. brizantha "MG-5". According to PAULINO et al. (2004), in areas with sandy soils and with the possibility of droughts, sowing at 
depths of around $4 \mathrm{~m}$ to $U$. brizantha "MG-5" is safer than conventional, where the sowing depth is close to $2 \mathrm{~cm}$.

The lower production of total dry straw was obtained at higher sowing depth $(16 \mathrm{~cm})$ of cover crops in both years (Table 1). This result was due to the delay in the emergence of these forages which subsequently damaged the light gathering of these plants, due to shading caused by corn that grew faster, so the photosynthetic rate of forage was reduced, resulting in less accumulation of carbohydrates and consequently in lower dry matter production of cover crops.

For cropping systems, note that intercropping corn with independent brachiarias species produced higher total dry straw in single corn, in both years (Table 1). However, in 2009, there was no significant difference between the straw total dry matter production of corn intercropped with $U$. ruziziensis and single corn. We also emphasize that the dry matter yield of corn was higher than the forages in a consortium, regardless of seeding depth of cover crops. According to BAYER (1996), the annual intake of straw for no tillage sytem in the cerrado region should be 10 to $12 \mathrm{t} \mathrm{ha}^{-1}$.

In the present study, the total quantity of dry straw at depths of 8 and $10 \mathrm{~cm}$, regardless of the forage species, were sufficient to supply the amount of straw to be added annually to the soil surface for maintenance and sustainability of the no tillage system. Regarding forage species, regardless of the depths, the total amounts of straw in the corn intercropping with $U$. brizantha and U. ruziziensis (Table 1), supplied the annual intake of straw reported by the authors above mentioned.

According to TRECENTI (2005), U. ruziziensis has been recommended for the crop-livestock integration, mainly by providing rapid ground cover, take high quality composition, excellent nutrient recycling, facilities and desiccation in its uniform of seed production. As the $U$. brizantha, we emphasize that although this plant is affected in the intercropping systems, its recovery is rapid after the corn harvest (PORTES et al., 2000), as with the U. ruziziensis.

Table 2 shows that there was a significant effect in the second growing season for corn grain yield within the different cropping systems.

Intercropping corn with $U$. ruziziensis and single corn provided higher yields, and both differed statically from the consortium with $U$. brizantha in 2009, which resulted in lower grain yield (Table 2). This occurred because the $U$. brizantha is more tolerant to shade the $U$. ruziziensis, so this forage competed more for water, light and nutrients with corn, to the point of harming the crop productivity. ANDRADE et al. (2004) found that with $50 \%$ and $70 \%$ of shade, the decreases in rates of dry matter accumulation of $U$. brizantha "Marandú" were $13 \%$ and $60 \%$, respectively, compared to the condition of full sun, allowing classify it as tolerant to shade. It is noted also that the U. brizantha "Marandú" presents more upright growth habit, increased plant height and leaf length in relation to $U$. ruziziensi. These vegetative characteristics allow better adaptation to low light and increased competition for light in consortium with corn.

These results corroborate to those obtained by CHIODEROLI et al. (2010), who found that for the same region and soil of this study and the corn autumn crop intercropped with $U$. ruzizienses led to the highest grain yield, differing from $U$. brizantha, which showed lower values, given the greater interference with corn, irrespective of the method used for sowing. Similar results were found by MELLO et al. (2007), who worked with a consortium of $U$. brizantha and corn in the same region and soil type, verified the interference exerted by foraging on corn when intercropped in the sowing row and broadcasted in full area on the day of corn sowing. BORGHI et al. (2006) and BORGHI \& CRUSCIOL (2007) also reported that intercropping corn with $U$. brizantha promoted, on average, lower grain yields of corn. However, PEQUENO et al. (2006) found that $U$. brizantha sown along with corn or broadcast between the rows of this culture at 16; 32 and 48 days after corn sowing did not differ significantly from the yield and green matter of the single corn. And GARCIA et al. (2010) also found that the consortium Urochloa and Panicum with corn did not affect yield components and grain yield in corn cropping in the cerrado region. 
TABLE 2. Average values of corn grain yield (CGY) in brachiaria intercropping system with corn, submitted to three depths of seed deposition mixed with fertilizer in no tillage corn. (Selvíria - MS, 2009 and 2010).

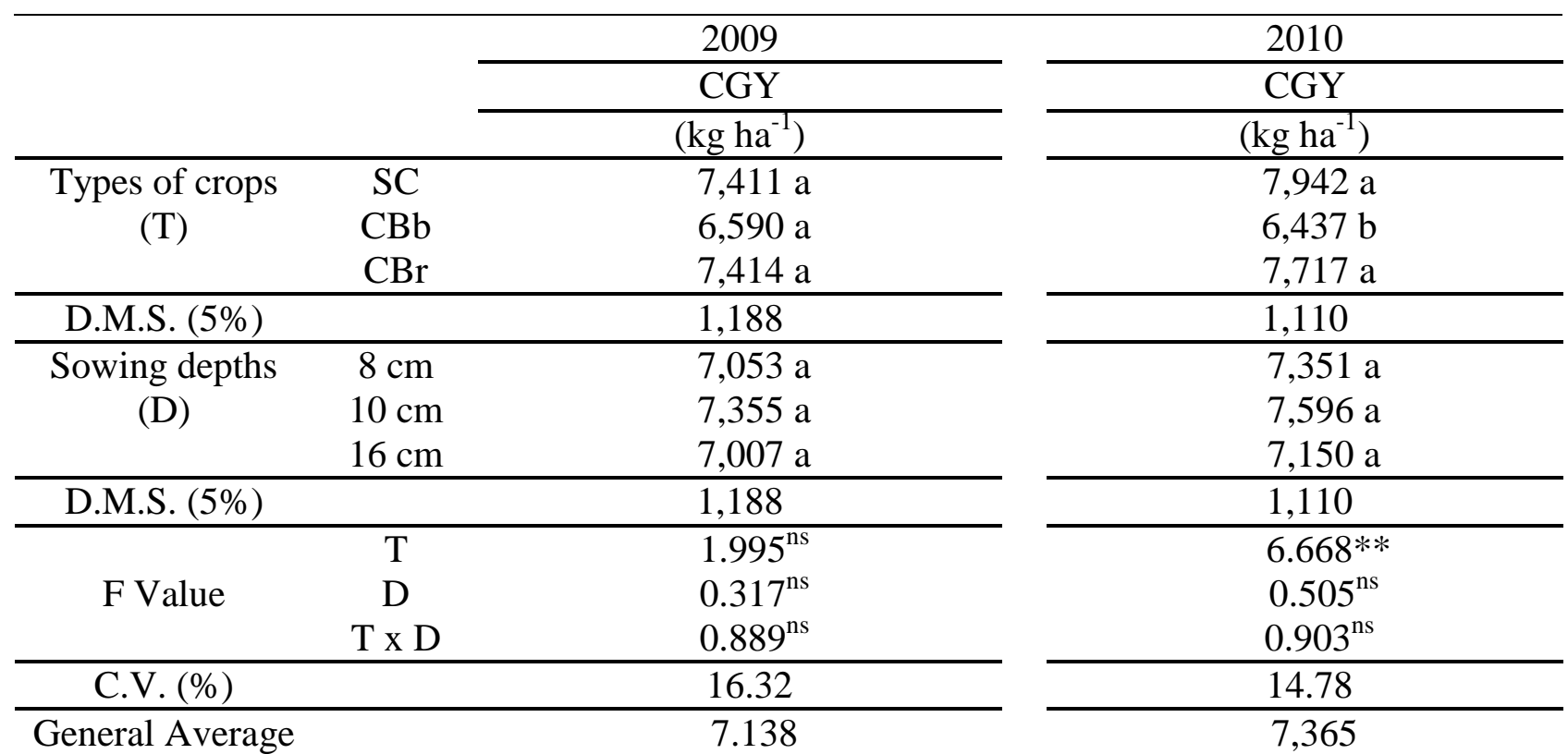

Averages followed by the same letter in the column do not differ by the Tukey's test, at a 5\% probability. Note: SC (single corn), $\mathrm{CBb}(\mathrm{Corn}+U$. brizantha $)$ and $\mathrm{CBr}(\mathrm{Corn}+U$. ruziziensis $)$.

The results obtained in this study differ from those obtained by PARIZ et al. (2011), which found that forage ( $U$. brizantha, $U$. decumbens and $U$. ruziziensis) broadcast intercropping, highlighting $U$. ruziziensis provided lower development of corn plants, as well as lower values of yield components and grain yield. According to FREITAS et al. (2005), the corn intercropped with forage, on average, reduce grain yield by $5 \%$.

GIMENES et al. (2008) found that the consortium of corn with $U$. brizantha, $U$. ruziziensis and $U$. decumbens species demonstrated feasibility for densities of 10 and $15 \mathrm{~kg} \mathrm{ha}^{-1}$ of forage sowing, and the relative density of $20 \mathrm{~kg} \mathrm{ha}^{-1}$, despite being indifferent to the mass parameter of 1,000 grains, negatively interfered on the final yield of the corn crop. CECCON (2007), however, found that plant population of $U$. ruziziensis did not affect grain yield of corn and its mass production, indicating that smaller populations can be used in order to save on deployment of the consortium.

It is noteworthy that the different results are related to the combination of several factors such as the population of forage, the time of its deployment, the sowing arrangements, the presence of weeds, applying herbicides, soil fertility and water conditions (ALVARENGA et al., 2006).

The corn grain yield was not significantly influenced by deposition depths of forages and fertilizer, in both years (Table 2). KLUTHCOUSKI et al. (2000), MACEDO (2009) and EUCLIDES et al. (2010) reported that, in general, the presence of forage did not affect corn grain yield in the cerrado region, and that the deposition of fertilizer sowing seeds mixed with the forage species, at greater depths, delays their emergence, in order to decrease competition with the crop grain producer. GROTTA (2008), working with three depths of furrowers for opening fertilizer deposition furrows $(11,14$ and $17 \mathrm{~cm})$, also found no effect on corn grain yield.

According to KLUTHCOUSKI et al. (2000) and FOLONI et al. (2009), deposition of sowing fertilizer mixed with seeds of forage species at depths below $5 \mathrm{~cm}$ allows the delayed germination and emergence in order to decrease competition with the crop grain producer. Therefore, as in this study the sowing depths $(8 ; 10$ and $16 \mathrm{~cm})$ of forage were lesser than reported above, this explains why it was observed corn grain yield similar to such treatments. 


\section{CONCLUSIONS}

The two consortiums of corn with Brachiaria produced similar amounts of straw, which are sufficient for the maintenance and stability of the no tillage in this lowland cerrado region.

The lower sowing depths $(8$ and $10 \mathrm{~cm}$ ) provided higher yields of forage dry matter and total Brachiaria straw.

The consortium with $U$. ruziziensis resulted in higher grain yield of corn as compared with the $U$. brizantha in 2010 .

The corn grain yield was not affected by sowing depths of brachiarias.

\section{REFERENCES}

ALVARENGA, R.C.; COBUCCI, T.; KLUTHCOUSKI, J.; WRUCK, F.J.; CRUZ, J.C.; GONTIJO NETO, M.M. A cultura do milho na integração lavoura-pecuária. Informe Agropecuário, Belo Horizonte, v.27, n.233, p.106-126, 2006.

ANDRADE, C.M.S.; VALENTIM, J.F.; CARNEIRO, J.C.; VAZ, F.A. Crescimento de gramíneas e leguminosas forrageiras tropicais sob sombreamento. Pesquisa Agropecuária Brasileira, Brasília, v.39, n.3, p.263-270, 2004.

BARDUCCI, R.S.; COSTA, C.; CRUSCIOL, C.A.C.; BORGHI, É.; PUTAROV, T.C.; SARTI, L.M.N. Produção de Brachiaria brizantha e Panicum maximum com milho e adubação nitrogenada. Archivos de Zootecnia, Córdoba, v.58, n.222, p.211-222, 2009.

BAYER, C. Dinâmica da matéria orgânica em sistemas de manejo de solos. 1996. 240 f. Tese (Doutorado em Ciência do Solo) - Universidade Federal do Rio Grande do Sul, Porto Alegre, 1996.

BORGHI, É.; CRUSCIOL, C.A.C.; COSTA, C.; MATEUS, G.P. Produtividade e qualidade das forragens de milho e de Brachiaria brizantha em sistema de cultivo consorciado. Revista Brasileira de Milho e Sorgo, Sete Lagoas, v.5, n.3, p.369-381, 2006.

BORGHI, É.; CRUSCIOL, C.A.C. Produtividade de milho, espaçamento e modalidade de consorciação com Brachiaria brizantha no sistema plantio direto. Pesquisa Agropecuária Brasileira, Brasília, v.42, n.2, p.163-171, 2007.

BRAMBILLA, J.A.; LANGE, A.; BUCHELT, A.C.; MASSAROTO, J.A. Produtividade de milho safrinha no sistema de integração lavoura-pecuária, na região de sorriso, Mato Grosso. Revista Brasileira de Milho e Sorgo, Sete Lagoas, v.8, n.3, p.263-274, 2009.

CECCON, G. Milho safrinha com solo protegido e retorno econômico em Mato Grosso do Sul. Revista Plantio Direto, Passo Fundo, v.16, n.97, p.17-20, 2007.

CECCON, G.; MATOSO, A.O.; NUNES, D.P. Germinação de Brachiaria ruziziensis em consórcio com milho em função da profundidade de semeadura e tipos de sementes. In: CONGRESSO NACIONAL DE MILHO E SORGO, 27., 2008, Londrina. Anais... Londrina: Associação Brasileira de Milho e Sorgo, IAPAR, Embrapa Milho e Sorgo, 2008. 1 CD-ROM

CHIODEROLI, C.A. Consorciação de braquiárias com milho outonal em sistema plantio direto como cultura antecessora da soja de verão na integração agricultura-pecuária. $2010.84 \mathrm{f}$.

Dissertação (Mestrado em Sistemas de Produção) - Universidade Estadual Paulista, Faculdade de Engenharia, Ilha Solteira, 2010.

CHIODEROLI, C.A.; MELLO, L.M.M.; GRIGOLLI, P.J.; SILVA, J.O.R.; CESARIN, A.L. Consorciação de braquiárias com milho outonal em plantio direto sob pivô central. Engenharia Agrícola, Jaboticabal, v.30, n.6, p.1101-1109, 2010.

EMBRAPA. EMPRESA BRASILEIRA DE PESQUISA AGROPECUÁRIA. Sistema brasileiro de classificação dos solos. 2.ed. Rio de Janeiro: CNPS, 2006. 306 p. 
EUCLIDES, V.P.B.; VALLE, C.B.; MACEDO, M.C.M.; ALMEIDA, R.G.; MONTAGNER, D.B.; BARBOSA, R.A. Brazilian scientific progress in pasture research during the first decade of XXI century. Revista Brasileira de Zootecnia, Viçosa, v.39, p.151-168, 2010. Supl. Especial.

FERREIRA, D.F. SISVAR: um programa para análises e ensino de estatística. Revista Symposium, Lavras, v.6, n.2, p.36-41, 2008.

FOLONI, J.S.S.; CUSTÓDIO, C.C.; POMPEI, F.P.; VIVAN, M.R. Instalação de espécie forrageira em razão da profundidade no solo e contato com fertilizante formulado NPK. Pesquisa Agropecuária Tropical, Goiânia, v.39, n.1, p.7-12, 2009.

FREITAS, F.C.L.; FERREIRA, L.R.; FERREIRA, F.A.; SANTOS, M.V.; AGNES, E.L.; CARDOSO, A.A.; JAKELAITIS, A. Formação de pastagem via consórcio de Brachiaria brizantha com o milho para silagem no sistema de plantio direto. Planta Daninha, Viçosa, v.23, n.1, p.49-58, 2005.

GARCIA, C.M.P.; ANDREOTTI, M.; TEIXEIRA FILHO, M.C.M.; PARIZ, C.M.; CELESTRINO, T.S.; COSTA, N.R.; BERGAMASCHINE, A.F. Desempenho agronômico e produtividade da cultura do milho consorciada com forrageiras dos gêneros Panicum e Brachiaria. In: REUNIÃO BRASILEIRA DE FERTILIDADE DO SOLO E NUTRIÇÃO DE PLANTAS, 29.,

REUNIÃO BRASILEIRA SOBRE MICORRIZAS, 13.; SIMPÓSIO BRASILEIRO DE MICROBIOLOGIA DO SOLO, 6.; E REUNIÃO BRASILEIRA DE BIOLOGIA DO SOLO, 8.; 2010, Guarapari. Anais... Guarapari: Sociedade Brasileira de Ciência do Solo, 2010. 1 CD-ROM.

GIMENES, M.J.; VICTORIA FILHO, R.; PRADO, E.P.; POGETTO, M.H.F.A.D.;

CHRISTOVAM, R.S. Interferência de espécies forrageiras em consórcio com a cultura do milho. Revista da FZVA, Uruguaiana, v.15, n.2, p.61-76, 2008.

GROTTA, D.C.C. Desempenho operacional de semeadora adubadora e perdas na colheita do milho em sistema plantio direto. 2008. 107 f. Tese (Doutorado em Produção Vegetal) -

Universidade Estadual Paulista, Faculdade de Ciências Agrárias e Veterinárias, Jaboticabal, 2008.

KLUTHCOUSKI, J.; COBUCCI, T.; AIDAR, H.; YOKOYAMA, L.P.; OLIVEIRA, I.P.; COSTA, J.L.S.; SILVA, J.G.; VILELA, L.; BARCELLOS, A.O.; MAGNABOSCO, C.U. Sistema Santa Fé - Tecnologia Embrapa: integração lavoura-pecuária pelo consórcio de culturas anuais com forrageiras, em áreas de lavoura, nos sistemas direto e convencional. Santo Antonio de Goiás: Embrapa Arroz e Feijão, 2000. 28p. (Circular Técnica, 38).

MACEDO, M.C.M. Integração lavoura e pecuária: o estado da arte e inovações tecnológicas. Revista Brasileira de Zootecnia, Viçosa, v.38, p.133-146, 2009. Supl. especial.

MELLO, L.M.M.; PANTANO, A.C.; NARIMATSU, K.C.P. Integração agricultura-pecuária em plantio direto: consorciação braquiária e milho. In: CONGRESSO BRASILEIRO DE ENGENHARIA AGRÍCOLA, 36., 2007, Bonito. Anais... Jaboticabal: Associação Brasileira de Engenharia Agrícola, 2007. 1 CD-ROM.

MELLO, L.M.M.; YANO, E.H.; NARIMATSU, K.C.P.; TAKAHASHI, C.M.; BORGHI, E. Integração agricultura-pecuária em plantio direto: produção de forragem e resíduo de palha após pastejo. Engenharia Agrícola, Jaboticabal, v.24, n.1, p.121-129, 2004.

OLIVEIRA, I.P. de; KLUTHCOUSKI, J.; YOKOYAMA, L.P.; DUTRA, L.G.; PORTES, T. de A.; SILVA, A.E. da; PINHEIRO, B. da S.; FERREIRA, E.; CASTRO, E. da M.; GUIMARÃES, C.M.; GOMIDE, J. de C.; BALBINO, L.C. Sistema Barreirão: recuperação/renovação de pastagens degradadas em consórcio com culturas anuais. Goiânia: Embrapa-CNPAF, 1996. 87 p.

(Documentos, 64).

PACHECO, L.P.; PIRES, F.R.; MONTEIRO, F.P.; PROCÓPIO, S.O.; ASSIS, R.L.; PETTER, F.A. Profundidade de semeadura e crescimento inicial de espécies forrageiras utilizadas para cobertura do solo. Ciência e Agrotecnologia, Lavras, v.34, n.5, p.1211-1218, 2010. 
PARIZ, C.M.; ANDREOTTI, M.; AZENHA, M.V.; BERGAMASCHINE, A.F.; MELLO, L.M.M.; LIMA, R.C. Produtividade de grãos de milho e massa seca de braquiárias em consórcio no sistema de integração lavoura-pecuária. Ciência Rural, Santa Maria, v.41, n.5, p.875-882, 2011.

PAULINO, T.S.; TSUHAKO, A.T.; PAULINO, V.T. Efeito do estresse hídrico e da profundidade de semeadura na emergência de Brachiaria brizantha cv. MG-5. Revista Científica Eletrônica de Agronomia, Garça, v.3, n.5, s/p., 2004.

PEQUENO, D.N.L.; MARTINS, E.P.; AFFERRI, F.S.; FIDELIS, R.R.; SIQUEIRA, F.L.T. Efeito da época de semeadura da Brachiaria brizantha em consórcio com o milho, sobre características agronômicas da cultura anual e da forrageira em Gurupi, estado do Tocantins. Amazônia: Ciência e Desenvolvimento, Belém, v.2, n.3, p.127-134, 2006.

PEREIRA, R.G.; ALBUQUERQUE, A.W.; CAVALCANTE, M.; PAIXÃO, S.L.; MARACAJÁ, P.B. Influência dos sistemas de manejo do solo sobre os componentes de produção do milho e Brachiaria decumbens. Revista Caatinga, Mossoró, v.22, n.1, p.64-71, 2009.

PORTES, T.A.; CARVALHO, S.I.C.; OLIVEIRA, I.P.; KLUTHCOUSKI, J. Análise do crescimento de uma cultivar de braquiária em cultivo solteiro e consorciado com cereais. Pesquisa Agropecuária Brasileira, Brasília, v.35, n.7, p.1349-1358, 2000.

RAIJ, B. van. Fertilidade do solo e adubação. São Paulo: Ed. Agronômica Ceres, 1991. 343 p.

REZENDE, A.V.; VILELA, H.H.; ALMEIDA, G.B.S.; LANDGRAF, P.R.C.; ANDRADE, G.A.; VIEIRA, P.F. Germinação de Sementes de forrageiras em diferentes profundidades de semeadura. In. CONGRESSO DE FORRAGICULTURA E PASTAGENS, 2., 2007, Lavras. Anais... Lavras: NEFOR, 2007. 1 CD-ROM.

RICHART, A.; PASLAUSKI, T.; NOZAKI, M.H.; RODRIGUES, C.M.; FEY, R. Desempenho do milho safrinha e da Brachiaria ruziziensis cv. Comum em consórcio. Revista Brasileira de Ciências Agrárias, Recife, v.5, n.4, p.497-502, 2010.

SILVA, E.T.; CUNHA, J.L.X.; MADALENA, J.A.; SILVA, J.A.C.; SILVA, W.T. Produção de milho (Zea mays L.) em consórcios com gramíneas forrageiras. Revista Caatinga, Mossoró, v.21, n.4, p.29-34, 2008.

TRECENTI, R. Técnicas de consórcio ajudam na formação de palha para o plantio direto. Revista Plantio Direto, Passo Fundo, v.86, n.2, 2005. 